\title{
Correction to: Effectiveness of Eribulin in Metastatic Breast Cancer: 10 Years of Real-World Clinical Experience in the United States
}

Sarah S. Mougalian (D) · Jonathan K. Kish · Jingchuan Zhang •

Djibril Liassou $\cdot$ Bruce A. Feinberg

Published online: May 16, 2021

(c) Springer Healthcare Ltd., part of Springer Nature 2021

Correction to:

Adv Ther (2021) 38:2213-2225

https://doi.org/10.1007/s12325-020-01613-6

In the original article, there was an error in the reported CBR level in the Disease Response section on page 6 . The correct value should read "The CBR was 56.7\% (95\% CI 52.3-61.0\%)".

The original article can be found online at https://doi. org/10.1007/s12325-020-01613-6.

S. S. Mougalian ( $₫)$

Yale Medical School, Yale Cancer Center,

New Haven, CT, USA

e-mail: sarah.mougalian@yale.edu

J. K. Kish · D. Liassou · B. A. Feinberg

Cardinal Health Specialty Solutions, Dublin, $\mathrm{OH}$, USA

J. Zhang

Eisai Inc., Woodcliff Lake, NJ, USA 